\title{
Oxidized LDL Downregulates ABCA1 Expression via MEK/ERK/LXR Pathway in INS-1 Cells
}

\author{
Jingya Lyu ${ }^{1,2}$, Kensaku Fukunaga ${ }^{2}$, Hitomi Imachi ${ }^{2}$, Seisuke Sato ${ }^{2}$, Toshihiro Kobayashi ${ }^{2}$, Takanobu Saheki ${ }^{2}$, \\ Tomohiro Ibata ${ }^{2}$, Takafumi Yoshimura ${ }^{2}$, Hisakazu Iwama ${ }^{3}$ and Koji Murao ${ }^{2, *}$ \\ 1 Department of Physiology, School of Medicine, Jinan University, 601 Huangpu Avenue West, Tianhe District, \\ Guangzhou 510632, China; jingylyu@med.kagawa-u.ac.jp \\ 2 Department of Endocrinology and Metabolism, Faculty of Medicine, Kagawa University, 1750-1, Miki-cho, \\ Kita-gun, Kagawa 761-0793, Japan; fukunaga@med.kagawa-u.ac.jp (K.F.); ihitomi@med.kagawa-u.ac.jp (H.I.); \\ seisuke-310@med.kagawa-u.ac.jp (S.S.); koba1987@med.kagawa-u.ac.jp (T.K.); \\ t-saheki@med.kagawa-u.ac.jp (T.S.); ibata@med.kagawa-u.ac.jp (T.I.); \\ yoshimura.takafumi@kagawa-u.ac.jp (T.Y.) \\ 3 Life Science Research Center, Kagawa University, 1750-1, Miki-cho, Kita-gun, Kagawa 761-0793, Japan; \\ iwama@med.kagawa-u.ac.jp \\ * Correspondence: mkoji@med.kgawa-u.ac.jp
}

Citation: Lyu, J.; Fukunaga, K.; Imachi, H.; Sato, S.; Kobayashi, T.; Saheki, T.; Ibata, T.; Yoshimura, T.; Iwama, H.; Murao, K. Oxidized LDL Downregulates ABCA1 Expression via MEK/ERK/LXR Pathway in INS-1 Cells. Nutrients 2021, 13, 3017. https://doi.org/10.3390/nu13093017

Academic Editor: J. Mark Brown

Received: 11 August 2021

Accepted: 24 August 2021

Published: 29 August 2021

Publisher's Note: MDPI stays neutral with regard to jurisdictional claims in published maps and institutional affiliations.

Copyright: (c) 2021 by the authors. Licensee MDPI, Basel, Switzerland. This article is an open access article distributed under the terms and conditions of the Creative Commons Attribution (CC BY) license (https:/ / creativecommons.org/licenses/by/ $4.0 /)$.

\begin{abstract}
Impaired insulin secretion is one of the main causes of type 2 diabetes. Cholesterol accumulation-induced lipotoxicity contributes to impaired insulin secretion in pancreatic beta cells. However, the detailed mechanism in this process remains unclear. In this study, we proved that oxidized low-density lipoprotein (OxLDL) reduced insulin content, decreased PDX-1 expression, and impaired glucose-stimulated insulin secretion (GSIS) in INS-1 cells, which were rescued by addition of high-density lipoprotein (HDL). OxLDL receptors and cholesterol content were increased by OxLDL. Consistently, OxLDL suppressed cholesterol transporter ABCA1 expression and transcription in a dose-dependent and time-dependent manner. Inhibition of MEK by its specific inhibitor, PD98059, altered the effect of OxLDL on ABCA1 transcription and activation of ERK. Next, chromatin immunoprecipitation assay demonstrated that liver $X$ receptor (LXR) could directly bind to ABCA1 promoter and this binding was inhibited by OxLDL. Furthermore, OxLDL decreased the nuclear LXR expression, which was prevented by HDL. LXR-enhanced ABCA1 transcription was suppressed by OxLDL, and the effect was cancelled by mutation of the LXR-binding sites. In summary, our study shows that OxLDL down-regulates ABCA1 expression by MEK/ERK/LXR pathway, leading to cholesterol accumulation in INS-1 cells, which may result in impaired insulin synthesis and GSIS.
\end{abstract}

Keywords: oxidized LDL; ABCA1; liver X receptor; MEK/ERK; insulin secretion; lipotoxicity

\section{Introduction}

Diabetes mellitus is one of the most common chronic metabolic diseases and the ninth major cause of death. According to the report from Japan Diabetes Society, 1 in every 7 Japanese is suffering from diabetes and 95\% of them are type 2 diabetes (T2D), which is characterized as impaired insulin secretion and insulin resistance [1]. The main cause for T2D is impaired insulin secretion from pancreatic beta cells, normally combined with abnormal lipid profiles, which exhibit higher concentration of plasma triglyceride and low-density lipoprotein (LDL)-cholesterol, as well as lower high-density lipoprotein (HDL)cholesterol concentration [2]. Of note, a clinical report shows that the oxidatively-modified lipoprotein, oxidized LDL (OxLDL) has a positive relationship with T2D in 7 years of follow-up, suggesting that oxidative stress induced by OxLDL may be one novel risk factor of T2D [3].

A previous study demonstrated that OxLDL decreased the mRNA level of proinsulin and insulin secretion from HIT-T15 cells [4]. Following this study, insulin resistance and 
cholesterol accumulation were found in adipocytes treated with OxLDL [5,6]. Recent study showed that blocking OxLDL by its antibody significantly improved insulin sensitivity and reduced plasma level of cholesterol and triglyceride in obese Rhesus Macaques [7], pointing out the association between OxLDL and diabetes. Oxidized LDL is able to be recognized by lectin-type oxidized LDL receptor 1 (LOX-1) [8,9]. Uptake of OxLDL by its receptor induces cholesterol accumulation in macrophages and promotes formation of foam cells, leading to the atherosclerotic plaque formation [10,11]. Preventing the uptake of OxLDL by knockout of its receptor reduces atherosclerosis in mice [12].

Cholesterol accumulation in pancreatic beta cells results in cell apoptosis and impaired insulin secretion, which is called lipotoxicity of beta cells [13]. As a key regulator of reverse cholesterol transport, the ATP-binding cassette transporter A1 (ABCA1) is a 254-kD membrane protein to export lipid from cytoplasm to apolipoproteins in vivo [14]. A previous study showed that mice lacking of the pancreatic $A B C A 1$ gene exhibited defective glucose-stimulated insulin secretion (GSIS) and glucose intolerance [15]. In vitro, absence of ABCA1 impaired GSIS and altered cholesterol homeostasis in pancreatic islets [16]. Our previous study proved that downregulation of ABCA1 by angiotensin II increased cholesterol content and impaired GSIS in INS-1 cells and pancreatic islets [17]. This evidence pindicates that pancreatic $A B C A 1$ expression is important to regulate the cholesterol content of beta cells and protect the function of beta cell in type 2 diabetes. Moreover, OxLDL has been demonstrated to reduce the expression of ABCA1 by inhibiting of liver $\mathrm{X}$ receptor (LXR) in HUVECs [18]. As a critical pathogenic marker of vascular atherosclerosis, there is accumulating evidence demonstrating that OxLDL increases cholesterol accumulation in macrophages and hepatocytes $[19,20]$, which contributes to increase the prevalence of metabolic syndrome and fatty liver disease $[20,21]$. However, the effect of OxLDL on cholesterol accumulation in pancreatic beta cells is not clear. Additionally, the detailed mechanism of OxLDL-regulated pancreatic ABCA1 is not completely understood.

In this study, we checked the effect of OxLDL on the GSIS, cholesterol content mediated by ABCA1 expression in INS-1 cells, and hypothesized that OxLDL might induce cholesterol accumulation by downregulation of ABCA1 expression, then impaired function of pancreatic beta cells.

\section{Materials and Methods}

\section{1. $O x L D L$ and $H D L$}

Oxidized LDL and HDL were purified from human plasma via ultracentrifugation to homogeneity as determined via agarose gel electrophoresis, which were purchased from BIO-RAD (5685-3557; 5685-2004).

\subsection{Cell Culture}

INS-1 cells, originally isolated from a rat insulinoma, were split every 7 days during 12 40 passages. These cells were maintained in RPMI1640 medium (Wako) supplemented with 10\% heat-inactivated fetal bovine serum (FBS; Dainippon Pharmaceutical Co., Ltd., Tokyo, Japan), $50 \mu \mathrm{M}$ beta-mercaptoethanol, $100 \mathrm{U} / \mathrm{mL}$ penicillin, and $100 \mu \mathrm{g} / \mathrm{mL}$ streptomycin. All cells were incubated in humidified $5 \% \mathrm{CO}_{2}$ at $37^{\circ} \mathrm{C}$. When $80 \%$ confluent, the cells were starved with RPMI 1640 media containing $0.5 \%$ FBS for $6 \mathrm{~h}$. After starvation, the cells were treated with varying doses of OxLDL or HDL for $24 \mathrm{~h}$ or varying time.

\subsection{Western Blot Analysis}

Proteins were separated by SDS-PAGE (7.5\%) and transferred to polyvinylidene difluoride membrane for immunoblotting. After blocking with skim milk, the membrane was incubated with the 1st antibody for ABCA1, LXR, TFIID, Lox-1 (Santa Cruz Biotechnology Inc., Dallas, CA, USA), or phospho-MEK, MEK, phospho-ERK1/2, ERK1/2 (Cell Signal Technology, Tokyo, Japan) at $4{ }^{\circ} \mathrm{C}$ overnight or GAPDH antibody (Biomol Research, Plymouth Meeting, Pennsylvania, USA) at room temperature for $1 \mathrm{~h}$ [17]. The membrane was then incubated with the HRP-linked rabbit or mouse secondary antibody (DakoCytomation) 
at room temperature for $1 \mathrm{~h}$. Protein bands were detected by ECL (GE Healthcare, Tokyo, Japan) under Luminescent image analyzer LAS-1000 Plus.

\subsection{Reverse Transcription-Quantitative, Real-Time Reverse Transcriptase-Polymerase} Chain Reaction

According to the manufacturer's protocol, total RNA was extracted by the RNA-Bee reagent and $1 \mu \mathrm{g}$ total RNA were synthesized with SuperScript II reverse transcriptase (Invitrogen). PCR was performed with LightCycler 480 SYBR Green Master (Roche) by using CFX96 Touch Real Time PCR Detection Systems (BIO-RAD). The sequences of the forward and reverse primers were referenced as previous studies $[17,22]$ and shown as follows. PDX-1: 5' $5^{\prime}$-TCACTGGAGCAGGGAAGTCC- $3^{\prime}$ and $5^{\prime}$-TTCCGCTGTGTAAGCACCTCC-3'; ABCA1: 5'-CCCGGCGGAGTAGAAAGG- ${ }^{\prime}$ and $5^{\prime}$-AGGGCGATGCAAACAAAGAC- $3^{\prime}$; GAPDH: $5^{\prime}$-CTCCCATTCTTCCACCTTTG- $3^{\prime}$ and $5^{\prime}$-ATGTAGGCCATGAGGTCCAC-3'. Each set of PCR reactions included water as a negative control and 5 dilutions of the standard. The results showed as the relative expression compared with control levels as described previously [23]. GAPDH was used as the reference gene.

\subsection{Mutagenesis}

To generate the construct of LXR-binding sites mutated $A B C A 1$ promoter, a construct containing $A B C A 1$ promoter (pABCA1-LUC) was used as a template and was mutated at 57 and -52 sites with a pair of primer showed following $5^{\prime}$-CACAGGCTTTGACC $\underline{A} A T A G \underline{G A A}$ CCTCTGCGCTCG-3' and 5'-GTGTCCGAAACTGGTTATCCTTGGAGACGCGAGC-3' tated nucleotides shown underlined) by PCR as described in site-directed mutagenesis kit. These mutations replace residues that are critical for mediating effects of LXR via its response sequence (TGACC $\underline{G}$ and $\underline{T A A C C T)}$ ).

\subsection{Luciferase Reporter Gene Assay}

Purified pABCA1-LUC was transfected into INS-1 by reagent Lipofectamine2000 (Life Technologies, Gaithersburg, MD, USA). After transfection, cells were maintained in a medium containing HDL or OxLDL for $24 \mathrm{~h}$ with or without pre-treatment with LY294002 $(10 \mu \mathrm{M})$, PD98095 $(10 \mu \mathrm{M})$, SP600125 $(10 \mu \mathrm{M})$, or SB203580 $(1 \mu \mathrm{M})$ to separately inhibit the phosphatidylinositol 3 kinase (PI3K), mitogen-activated protein kinase (MEK), c-Jun N-terminal kinase (JNK), or p38 mitogen-activated protein kinase (p38 MAPK) signaling pathway for $30 \mathrm{~min}$ [24]. Then these cells were lysed by buffer, and the $A B C A 1$ promoter activity was measured according to the manufacturer's instructions (ToyoInk; Tokyo, Japan).

\subsection{Chromatin Immunoprecipitation (ChIP) Assay}

ChIP assay was performed by the ChIP-IT ${ }^{\mathrm{TM}}$ kit (Active Motif, Tokyo, Japan) according to the manufacturer's instructions. Chromatin was immunoprecipitated with rabbit LXR antibody (Santa Cruz Biotechnology Inc., Dallas, CA, USA) by using control IgG as a negative control. DNA containing the putative LXR-binding sites on rat $A B C A 1$ promoter was amplified by PCR using forward primer 5'-GCTTTCTGCTGAGTGACTGAACTAC-3' and reverse primer: $5^{\prime}$-GAATTACTGCTTTTTGCCGCG-3' as described previously [17]. PCR was performed using TAKARA PCR thermal cycler MP in the following amplification conditions: $95^{\circ} \mathrm{C}$ for $5 \mathrm{~min}$, followed by 36 cycles of $95^{\circ} \mathrm{C}$ for $20 \mathrm{~s}, 59^{\circ} \mathrm{C}$ for $30 \mathrm{~s}$, and $72{ }^{\circ} \mathrm{C}$ for $30 \mathrm{~s}$. PCR products (229 bp) were detected by $3 \%$ agarose gel electrophoresis.

\subsection{Glucose-Stimulated Insulin Secretion (GSIS)}

INS-1 cells were starved in Krebs-Ringer bicarbonate (KRB) buffer containing $120 \mathrm{mM}$ $\mathrm{NaCl}, 5 \mathrm{mM} \mathrm{KCl}, 1.1 \mathrm{mM} \mathrm{MgCl}_{2}, 2.5 \mathrm{mM} \mathrm{CaCl}_{2}, 25 \mathrm{mM} \mathrm{NaHCO}_{3}$, and $0.1 \%$ bovine serum albumin (pH 7.4) for $1 \mathrm{~h}$. After that, cells were rested in KRB buffer containing $3.3 \mathrm{mM}$ glucose for $1 \mathrm{~h}$, and then the medium was changed into KRB buffer containing $3.3 \mathrm{mM}$ glucose or $16.7 \mathrm{mM}$ glucose for $1 \mathrm{~h}$. The supernatant and cell protein was harvested and 
used for insulin measurement by ELISA kit (Shibayagi, Shibukawa, Japan). The data was normalized by the protein concentration as described previously [17].

\subsection{Cholesterol Content Assay}

As described previously, total cholesterol was measured by a colorimetric assay, which utilizes reagents widely used for the measurement of cholesterol in conjunction with a random-access chemistry analyzer ARCHITECT c8000 [25]. The cholesterol concentration was normalized to protein concentration $(\mu \mathrm{g} / \mu \mathrm{L})$ each.

\subsection{Oil Red O Stain}

INS- 1 cells were seeded on coverslips. After varying treatments, cells were fixed by $4 \%$ paraformaldehyde (PFA) for $30 \mathrm{~min}$ at room temperature. After washing three timed with phosphate-buffered saline (PBS; pH 7.2), fixed cells were incubated with Oil Red O solution for $15 \mathrm{~min}$. After washing three times with PBS, cells were incubated with hematoxylin solution for $30 \mathrm{~s}$ to stain nuclei. After washing three times with PBS, cells were mounted. Pictures were taken by upright microscope (Olympus BX-51/DP-72).

\subsection{Statistical Analysis}

Data were expressed as mean \pm SEM. Results were analyzed by one-way ANOVA and Student's $t$ test. $p<0.05$ was considered as statistically significant. All experiments were performed at least three times.

\section{Results}

\subsection{Glucose-Stimulated Insulin Secretion (GSIS) Was Impaired by OxLDL-Treatment in INS-1 Cells}

To analyze the effects of OxLDL on insulin secretion, we used rat insulinoma cell line, an INS-1 cell that has a physiological insulin secretion stimulated by increasing glucose concentration. Our results showed that INS-1 cells treated with OxLDL for $24 \mathrm{~h}$ could not secrete more insulin in response to high glucose (Figure 1A). A previous study showed that high-density lipoprotein (HDL) protected insulin secretion from pancreatic beta cells in high-glucose condition [26] and prevented beta cell from apoptosis and oxidative stress induced by OxLDL [27]. In this study, we found that OxLDL with HDL treatment improved impaired insulin secretion, while treatment with only HDL did not enhance this process (Figure 1A). Compared to the fold of insulin release response to high glucose stimulation in control group $(1.55 \pm 0.28)$ and HDL group $(1.929 \pm 0.22)$, OxLDL remarkably reduced the fold to $0.59 \pm 0.12$ while treatment with both HDL and OxLDL rescued the fold to $1.51 \pm 0.17$ (Figure 1B). At the same time, the total insulin content in INS-1 cells with OxLDL was significantly reduced to $86.82 \pm 11.11 \%$ of control while HDL rescued it to $96.72 \pm 4.44 \%$ of control (Figure 1C). At the same time, the mRNA expression of PDX-1, a critical transcription factor of insulin, was significantly decreased by OxLDL and the addition of HDL protected the basic level of PDX-1 mRNA expression (Figure 1D). These data demonstrated that OxLDL reduced insulin synthesis and impaired GSIS in INS-1 cells and HDL could protect beta cell function.

\subsection{OxLDL Induced Cholesterol Accumulation in INS-1 Cells}

In pancreatic beta cells, impaired insulin secretion could be induced by lipid accumulation [15]. As shown in Figure 2A, treatment with OxLDL for $24 \mathrm{~h}$ increased cholesterol content in a dose-dependent manner and the cholesterol accumulation was reduced by the addition of HDL, while only HDL treatment did not affect cholesterol content in INS-1 cells. This was also confirmed by Oil Red O stain that the number and size of lipid droplets were increased by OxLDL, which was reduced by addition of HDL (Figure 2B), confirming that cholesterol accumulation induced by OxLDL contributed to impaired beta cell function. 

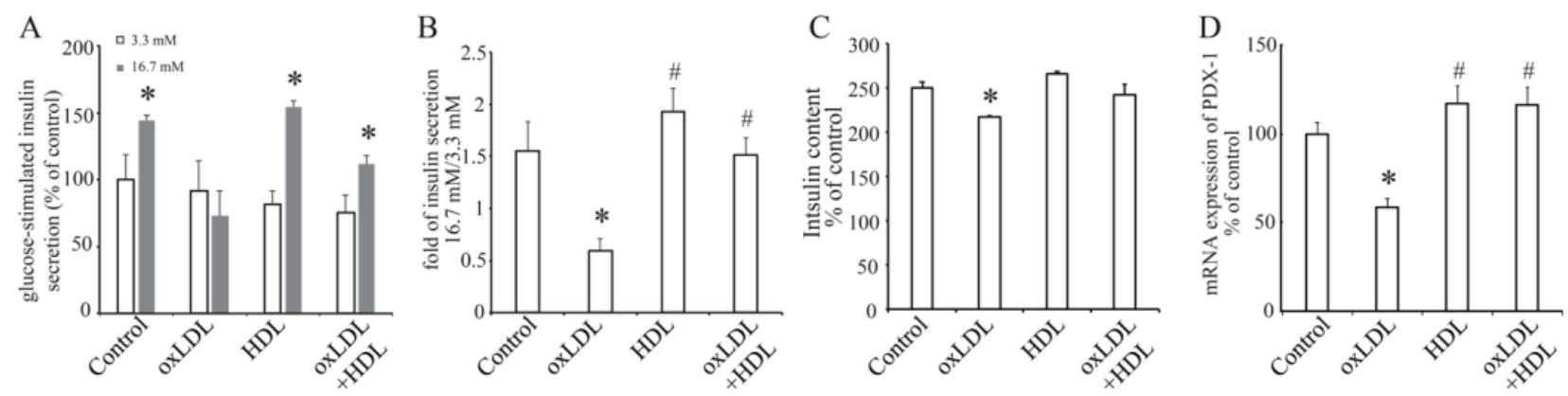

Figure 1. The effect of OxLDL on insulin secretion and synthesis in INS-1 cells. (A), glucose-stimulated insulin secretion (GSIS) in INS-1 cells treated with OxLDL at $50 \mu \mathrm{g} / \mathrm{mL}$, HDL at $10 \mu \mathrm{g} / \mathrm{mL}$ or both. White bar, stimulation with glucose at $3.3 \mathrm{mM}$; gray bar, stimulation with glucose at $16.7 \mathrm{mM}$. (B), fold of insulin secretion from $3.3 \mathrm{mM}$ glucose to16.7 $\mathrm{mM}$ glucose in INS-1 cells. (C), the total insulin content in INS-1 cells treated by OxLDL and HDL. (D), the effect of OxLDL and HDL on mRNA expression of PDX-1. The ratio is shown as percent of control. Data is presented as the mean \pm SEM ( $n=3)$ of separate experiments for each group. (A), ${ }^{*} p<0.05$ compared to white bar in each group. (B-D), ${ }^{*} p<0.05$ compared to control; \# $p<0.05$ compared to OxLDL.

A

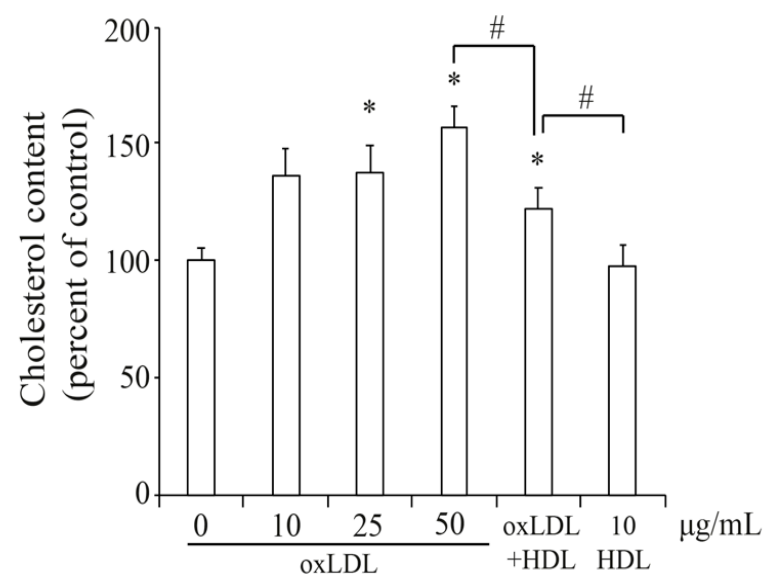

B

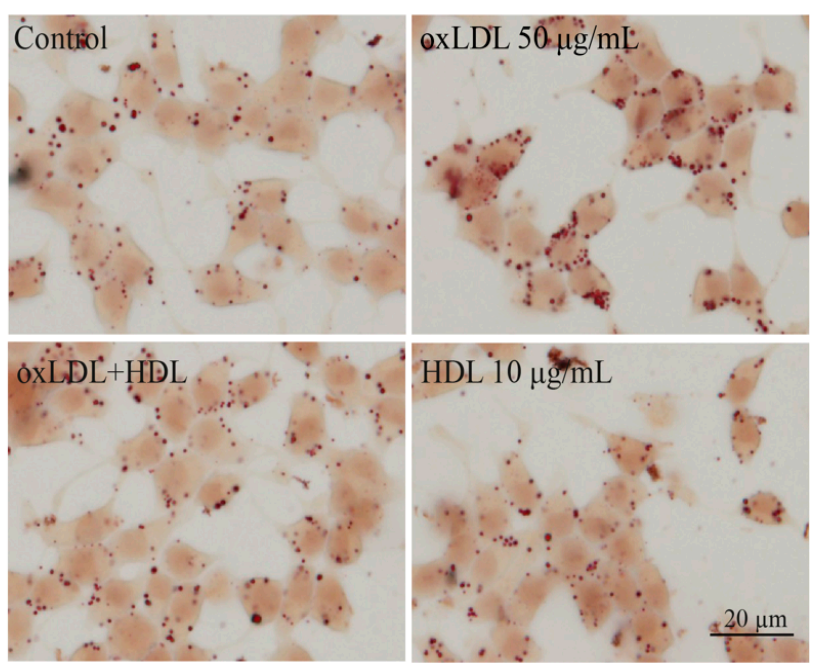

Figure 2. The effect of OxLDL on the cholesterol accumulation in INS-1 cells. (A). Percentage of cholesterol content normalized by protein concentration referred to control is presented as the mean \pm SEM $(n=3)$ of separate experiments in the graph. ${ }^{*} p<0.05$ compared to control; \# $p<0.05$ compared to OxLDL + HDL. (B) Oil Red O stain of INS-1 cells treated with OxLDL or plus HDL. Bar $=20 \mu \mathrm{m}$.

\subsection{OxLDL Decreased the ABCA1 Expression in INS-1 Cells}

As an important transporter of cholesterol, ABCA1 facilitates cholesterol out of cytoplasm to reduce cholesterol content. Then we examined the effect of OxLDL at varying concentration $(0 \sim 100 \mu \mathrm{g} / \mathrm{mL})$ on ABCA1 expression and found that OxLDL remarkably decreased ABCA1 expression in a dose-dependent manner in INS-1 cells (Figure 3A). This was confirmed by the results of real-time PCR (Figure 3B). Since OxLDL at $50 \mu \mathrm{g} / \mathrm{mL}$ efficiently decreased the protein and mRNA level of ABCA1, we used this concentration of OxLDL to treat INS-1 cells for varying time $(0 \sim 24 \mathrm{~h})$ and found it decreased the protein and mRNA expression of ABCA1 expression in time-dependent manner (Figure 3C,D). Furthermore, we found that HDL induced ABCA1 expression in INS-1 cells and prevented the reduction of ABCA1 induced by OxLDL (Figure 3E,F). These results pointed out that OxLDL downregulated ABCA1 expression and might induce cholesterol accumulation in INS-1 cells. 
A

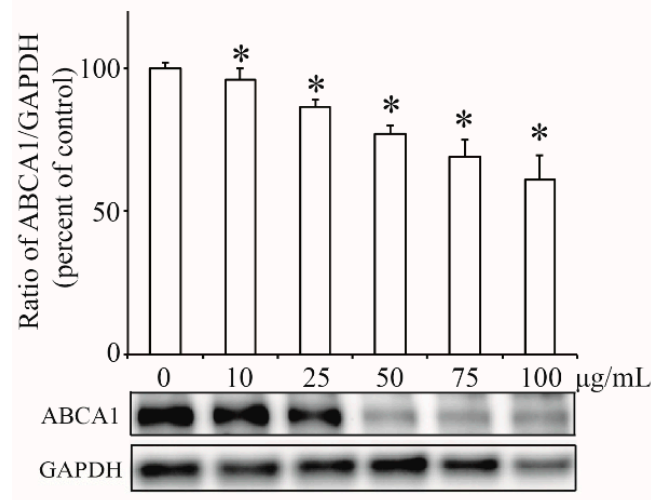

B

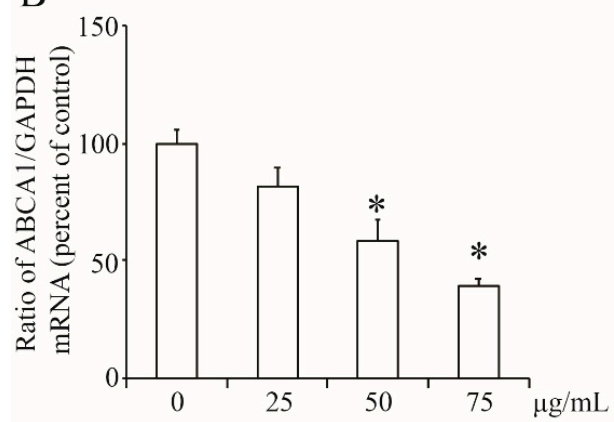

$\mathrm{C}$

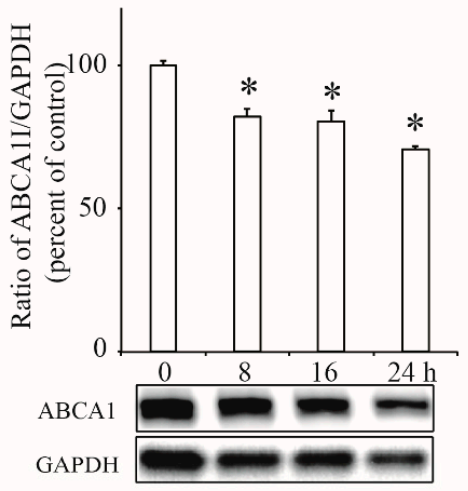

$\mathrm{D}$

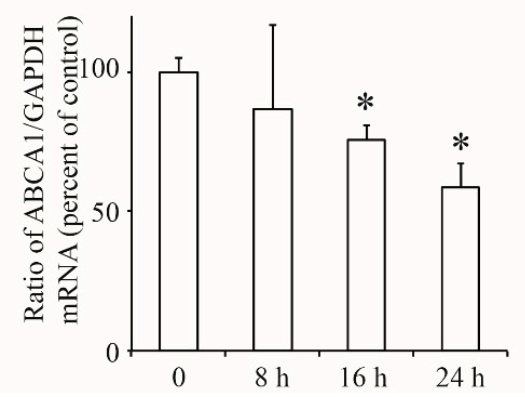

$\mathrm{E}$

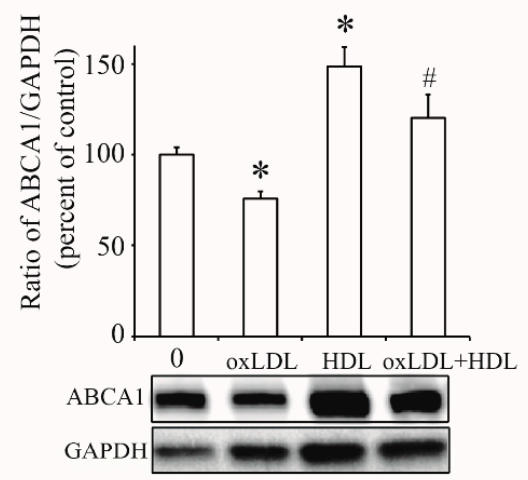

$\mathrm{F}$

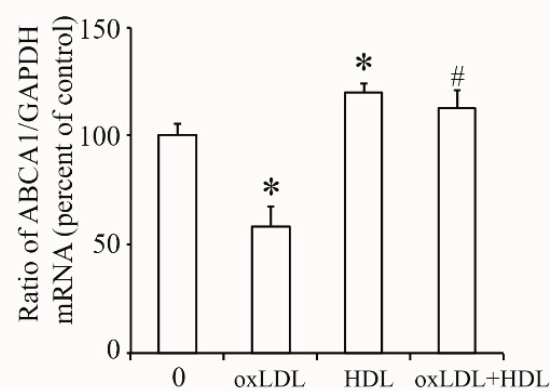

Figure 3. The effect of OxLDL on the expression of ABCA1 in INS-1 cells. $(\mathbf{A}, \mathbf{B})$, the protein and mRNA levels of ABCA1 in INS-1 cells treated with OxLDL at varying concentration $(0,10,25,50,75,100 \mu \mathrm{g} / \mathrm{mL})$. (C,D), the protein and mRNA level of ABCA1 in INS-1 cells with OxLDL at $50 \mu \mathrm{g} / \mathrm{mL}$ for varying time $(0,8,16,24 \mathrm{~h})$. (E,F), the protein and mRNA level of ABCA1 in INS-1 cells with OxLDL at $50 \mu \mathrm{g} / \mathrm{mL}$ or HDL at $10 \mu \mathrm{g} / \mathrm{mL}$. The ratio of ABCA1 to GAPDH is shown as percent of control. The data is presented as the mean $\pm \operatorname{SEM}(n=3)$ of separate experiments for each treatment group. ${ }^{*} p<0.05$ compared to 0 ; $\# p<0.05$ compared to OxLDL.

\subsection{OxLDL Suppressed the Transcription of ABCA1 via LOX-1/MEK/ERK Signaling Pathway in INS-1 Cells}

To further investigate the effect of OxLDL on the transcription of $A B C A 1$ gene, we used a constructed luciferase reporter plasmid containing the promoter region of $A B C A 1$. As shown in Figure 4A, OxLDL suppressed the promoter activity of $A B C A 1$ in a dosedependent manner while it was enhanced by addition of HDL. To identify the signaling pathway involved in OxLDL-suppressed $A B C A 1$ transcription, we used several inhibitors LY (LY294002, $10 \mu \mathrm{M})$, PD (PD98095, $10 \mu \mathrm{M})$, SP (SP600125, $10 \mu \mathrm{M})$ or SB (SB203580, $1 \mu \mathrm{M})$ to separately inhibit the PI3K, MEK, JNK, or p38 MAPK signaling pathway. As shown in Figure $4 B$, only inhibition of the MEK pathway by PD cancelled the effect of OxLDL on $A B C A 1$ promoter activity (Figure $4 \mathrm{~B}$ ), suggesting that OxLDL may regulate ABCA1 expression via MEK signaling pathway. Further, the activation of MEK/ERK (extracellular signal-regulated kinase) was stimulated by treatment with OxLDL for a different time (0 60 min) in INS-1 cells (Figure 4C). Ser217/221-phosphorylated MEK was activated from $5 \mathrm{~min}$ and peaked at $15 \mathrm{~min}$ after OxLDL treatment while Thr202/Tyr204 phosphorylation of ERK was detected from $5 \mathrm{~min}$ to $15 \mathrm{~min}$ (Figure 4C). Next, inhibition of MEK by PD98095 cancelled the activation of ERK induced by OxLDL (Figure 4D). Lectin-like OxLDL receptor-1 (LOX-1) was identified as a major receptor for the uptake of OxLDL [9] and activation of ERK pathway was shown to be mediated by LOX-1 [28]. In our study, the expression of LOX-1 was significantly increased in INS-1 cells (Figure 4E), suggesting that OxLDL suppressed $A B C A 1$ transcription via LOX-1/MEK/ERK pathway in INS-1 cells. 

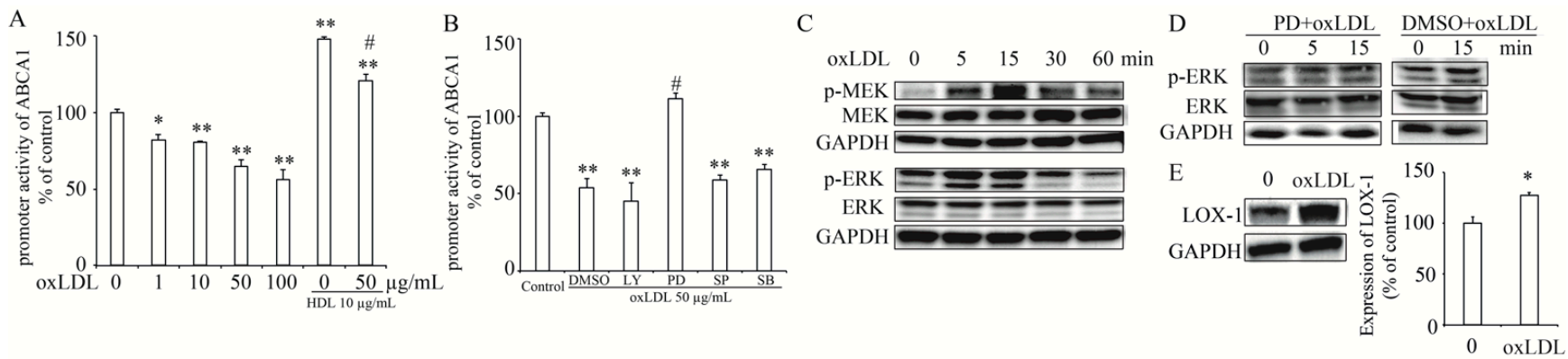

Figure 4. OxLDL suppressed $A B C A 1$ promoter activity via MEK/ERK pathway in INS-1 cells. (A), the effect of OxLDL or HDL on $A B C A 1$ promoter activity. (B), the effects of a PI3K inhibitor LY294002 (LY), a MEK inhibitor PD98059 (PD), a JNK inhibitor SP600125 (SP) or a p38 MAPK inhibitor SB203580 (SB) with or without OxLDL on $A B C A 1$ promoter activity. Percentage of promoter activity is referred to control. (C), phosphorylation of MEK at Ser217/221 and ERK at Thr 202/Tyr 204 in INS-1 cell treated with OxLDL. (D), phosphorylation of ERK at Thr 202/Tyr 204 after inhibition of MEK by PD98059 (PD) in INS-1 cells treated with OxLDL. (E), the protein expression of LOX-1 in INS-1 cells treated with OxLDL. The ratio is shown as percent of control.Data is presented as the mean $\pm \operatorname{SEM}(n=3)$ of separate experiments for each treatment group. ${ }^{*} p<0.05,{ }^{* *} p<0.01$ compared to 0 or control; \# $p<0.05$ compared to OxLDL at $50 \mu \mathrm{g} / \mathrm{mL}$ or DMSO plus OxLDL.

\subsection{LXR Involved in the Process of OxLDL-Suppressed ABCA1 Expression}

Next, we tried to search a transcription factor of the $A B C A 1$ gene, which is downstream of the MEK/ERK pathway. Previous studies proved that transcription factor, liver $\mathrm{X}$ receptor (LXR), is able to regulate $A B C A 1$ transcription combined with retinoid $\mathrm{X}$ receptor (RXR) $[18,29]$ and serves as a downstream of MEK/ERK pathway in INS-1 cells [17]. In the present study, we used chromatin immunoprecipitation (ChIP) assay to confirm that LXR could directly bind to the $A B C A 1$ promoter region in INS-1 cells (Figure 5A) and ChIPreal time PCR showed that this binding was significantly reduced by the treatment with OxLDL (Figure 5B). Moreover, OxLDL remarkably decreased nuclear expression of LXR while addition of HDL rescued this reduction (Figure 5C), indicating that OxLDL inhibited $A B C A 1$ transcription by LXR. When we overexpressed LXR and its cotransfector RXR in INS-1 cells, $A B C A 1$ promoter activity was enhanced, while only overexpression of RXR had no effect on $A B C A 1$ promoter activity (Figure 5D). However, the LXR-enhanced $A B C A 1$ promoter activity was suppressed by treatment of OxLDL. Further, when we mutated the LXR-binding sites (GATAGT to $\underline{A} A T A G \underline{G}$ ) in $A B C A 1$ promoter region, treatment with OxLDL, PD plus OxLDL, or overexpression of RXR had no stimulatory effect on this mutated promoter activity (Figure 5E). These findings supported the idea that OxLDL inhibited ABCA1 transcription by LXR in INS-1 cells. 
A

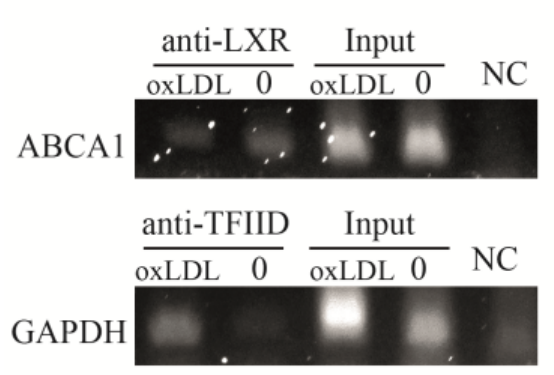

B

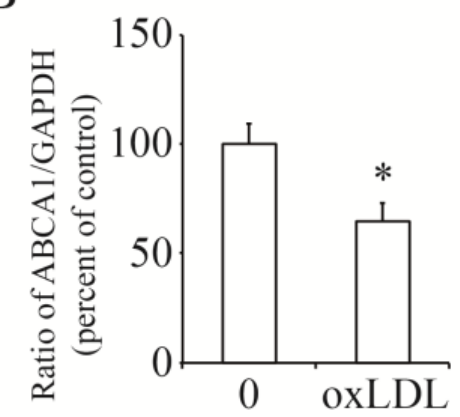

C

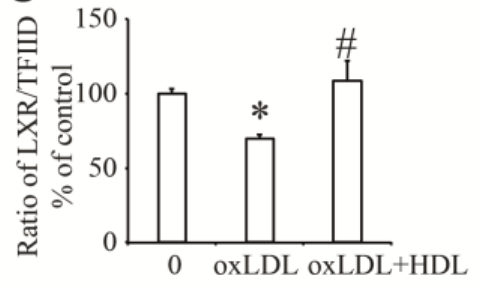

LXR

TFIID

$\mathrm{E}$
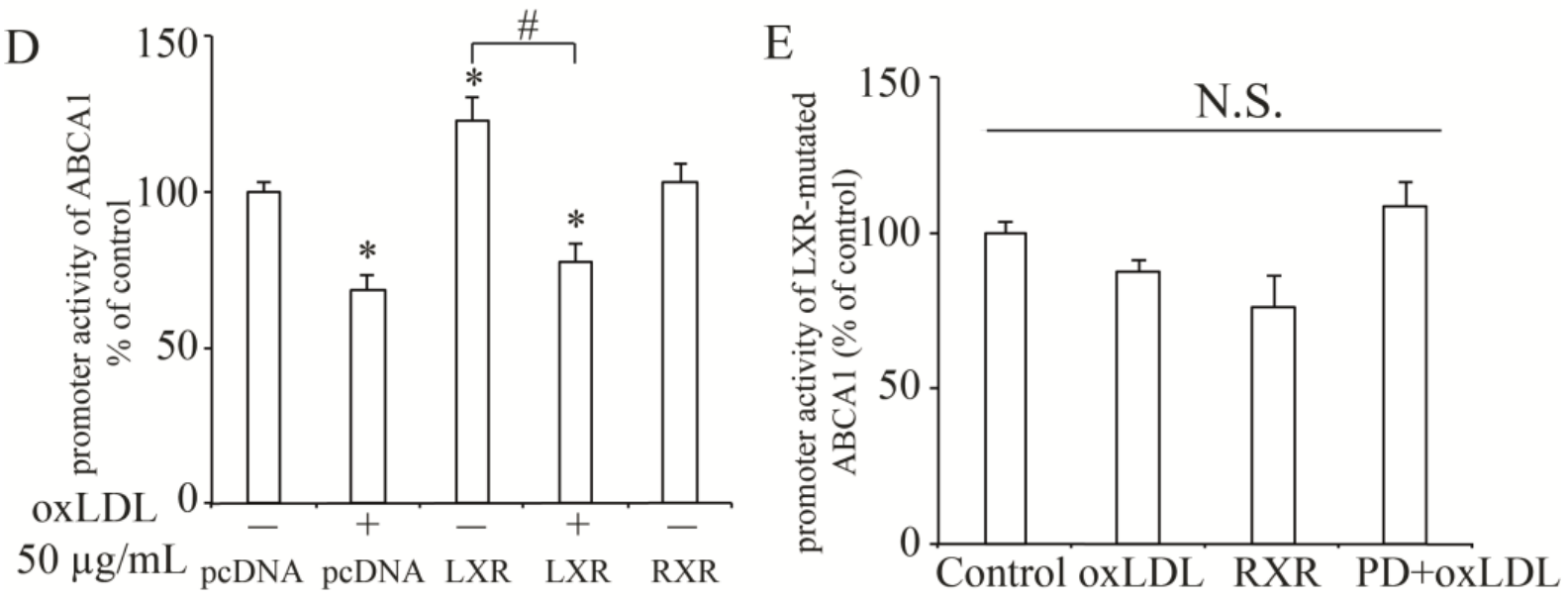

Figure 5. Roles of transcription factor, LXR in OxLDL-suppressed ABCA1 transcription. (A), the direct binding of LXR to $A B C A 1$ promoter. LXR specifically immunoprecipitated $A B C A 1$ chromatin (anti-LXR) while TFIID specifically immunoprecipitated GAPDH chromatin (anti-TFIID) in INS-1 cells by ChIP assay. No ChIP was detected when the chromatin was immunoprecipitated with negative control IgGs (NC). Input was shown as a positive control. There is no band detected when the templates were amplified by negative primer. (B), the effect of OxLDL on LXR-binding to $A B C A 1$ promoter by ChIP-real time PCR. (C), the nuclear abundance of LXR protein in INS-1 cells treated with OxLDL or OxLDL plus HDL. (D), the role of LXR in $A B C A 1$ promoter activity with OxLDL treatment. (E), the effect of OxLDL or inhibition of MEK on the LXR-binding sites (GATAGT to AATAGG) mutated $A B C A 1$ promoter activity. ${ }^{*} p<0.05$ compared to control (0, pcDNA). $\# p<0.05$ compared to OxLDL at $50 \mu \mathrm{g} / \mathrm{mL}$ (C). \# $p<0.05$ compared to LXR group (D). N.S., No significance.

\section{Discussion}

In the present study, we investigated the effect of OxLDL on dysfunction of pancreatic beta cells in detail. Our results showed that OxLDL inhibited GSIS, insulin content, and PDX-1 expression by cholesterol accumulation, which might be induced by suppressing pancreatic ABCA1 via MEK/ERK/LXR pathway in the pancreatic beta cell line, INS-1 cells.

OxLDL induces cholesterol accumulation, which is caused by down-regulated ABCA1 expression via MEK/ERK/LXR pathway. PDX-1 expression is reduced by OxLDL. As a result, insulin synthesis and glucose-stimulated insulin secretion (GSIS) is impaired. C, cholesterol; P, phosphorylation of MEK or EKR.

OxLDL was found to be linked to pathologic conditions related to cardiovascular diseases (CVDs), including diabetes mellitus, obesity, and metabolic syndrome. It has been shown that high levels of OxLDL, glucose, insulin resistance, and free fatty acid with low levels of HDL cholesterol result in the upregulation of scavenger receptor, thereby contributing to T2D and related atherosclerosis [30]. A clinical study on patients with metabolic syndrome followed up for 20 years showed that incidence of hyperglycemia, hypertriglyceridemia, and abdominal obesity increased, closely associating with a higher OxLDL level [21]. This study is confirmed by a following study that OxLDL exhibited a positive relationship with T2D in 7 years of follow-up [3], pointing out the harmful effect of OxLDL on inducing T2D. In vivo experiments demonstrated that blocking of OxLDL 
by its antibody improves insulin sensitivity [7]. In vitro, proinsulin synthesis and insulin secretion were suppressed by OxLDL [4] and cholesterol accumulation contributed to impaired insulin secretion from beta cells in the condition of high glucose [31]. In this study, we found OxLDL suppressed insulin synthesis and impaired GSIS in INS-1 cells and these effects were prevented by addition of HDL, confirming with previous research that HDL protected beta cells from apoptosis and oxidative stress induced by OxLDL [27]. Clinical study showed that HDL significantly improved glucose tolerance and increased plasma insulin by stimulating ABCA1 expression in T2D patients [32]. Moreover, in high-glucose condition, HDL protected insulin secretion and this effect was a ABCA1-dependent manner in pancreatic beta cells [26]. Consistently in our study, HDL stimulated ABCA1 expression and transcription in INS-1 cells. These evidences indicate the important role of ABCA1 in protecting insulin secretion in pancreatic beta cells.

Accumulation of cholesterol content in pancreatic islets, either in $o b / o b$ mice or in cholesterol-overloaded beta cell line, impairs insulin release response to glucose [33]. Consistently, high levels of cholesterol content in pancreatic islets and reduction of insulin secretion are detected in mice lacking beta cell ABCA1 $[15,16]$, suggesting that cholesterol accumulation induced by absence of ABCA1 may induce dysfunction of beta cells. A recent study has demonstrated that in ApoE-knockout mice with nicotine-pretreatment, enhancement of OxLDL uptake by macrophages aggravated atherosclerotic plaque formation through downregulation of ABCA1 [11]. In this study, we found cholesterol content was increased by OxLDL while insulin content and GSIS were decreased by OxLDL in INS-1 cells. In agreement with the previous report, we found OxLDL remarkably suppressed ABCA1 expression of INS-1 cells in a dose-dependent and time-dependent manner. A previous study indicated that pancreatic ABCA1 played an important role in glucose homeostasis regulated by rosiglitazone [15]. Additionally, our previous studies showed that an analogue of the glucagon-like peptide 1 (GLP-1) and insulin-like growth factor-1 (IGF-1) could stimulate the expression of ABCA1 and enhance insulin secretion in pancreatic beta cells while angiotensin II and TNF-alpha have the opposite effects on it [17,25,34-36]. These results suggested that decreased cholesterol content by upregulation of ABCA1 with several treatments could protect pancreatic beta cells from dysfunction. ABCA1 is firstly identified as a mutated molecule in Tangier Disease, with deficiency of high-density lipoprotein (HDL), accumulation of cholesterol in many cases, and glucose intolerance developing into diabetes [37]. A clinical report showed that four Japanese patients with Tangier Disease and T2D exhibited lower value of the insulinogenic index insulin compared to non-diabetic TD patients [38], indicating that cholesterol content and ABCA1 may be critical for insulin secretion.

Uptake of OxLDL by its receptors plays an important role in increasing oxidative stress and promoting foam cells' formation. Previous evidence showed that uptake of OxLDL was increased by upregulation of the scavenger receptor CD36 [10]. However, increasing the uptake of OxLDL by over-expressing CD36 did not enhance the lipotoxicity but induced more apoptosis of INS-1 cells [39], showing that there might be other receptors involved in OxLDL impaired GSIS. Previously, blocking LOX-1 by its antibody attenuated OxLDL-stimulated ER stress in endothelial cells [40]. Consistently, we found that the expression LOX-1 was elevated by the treatment of OxLDL, and HDL rescued the effect of OxLDL on dysfunction of INS-1 cells.

One of the goals in this study was to study the signaling pathway activation involved in OxLDL-mediated $A B C A 1$ gene expression. Present results showed that OxLDL suppressed $A B C A 1$ promoter activity and only inhibition of MEK by its specific inhibitor, PD98059 altered this effect, suggesting that MEK is required in OxLDL-regulated $A B C A 1$ transcription. Moreover, phosphorylation of MEK at Ser217/221 sites was activated by the treatment of OxLDL. Activation of MEK is able to phosphorylate mitogen-activated protein kinases (MAPKs), which are a family of serine/threonine protein kinases to modulate cell growth and differentiation [41]. ERK, one member of the MAPK family, contains p44 (ERK1) and p42 (ERK2) and is activated by phosphorylation of threonine and tyrosine 
residues by MEK [42]. ERK signaling is able to be stimulated to regulate function of vascular smooth muscle cells via OxLDL receptors [28]. In our study, MEK/ERK pathway was activated by the treatment of OxLDL, and this was cancelled by inhibition of MEK, which may contribute to the dysfunction of pancreatic beta cells. In our previous study, the MEK/ERK pathway activated by angiotensin II type 1 receptor (AT1) was shown to regulate pancreatic $A B C A 1$ promoter activity [17]. A recent report showed that AT1 could be activated by OxLDL via binding to LOX-1 [43], pointing out that OxLDL may stimulate MEK/ERK phosphorylation. Consistently in present study, our results showed that activation of MEK/ERK mediated OxLDL-inhibited $A B C A 1$ transcription activity in INS-1 cells.

Several studies demonstrated that inhibition of ERK1/2 and activation of liver $X$ receptor (LXR) synergistically reduced atherosclerotic lesions in ApoE-deficient mice [44] and activation of MEK/ERK modulates LXR-dependent ABCA1 expression [45]. LXR is expressed in a variety of tissues including the pancreas and is well-known in regulating lipid homeostasis and metabolism, facilitating cholesterol efflux from cells, and protecting the cells from lipid toxicity [46]. LXR/RXR heterodimers, upon binding to LXR response elements (LXREs), lead to the transcription of target genes, including $A B C A 1$ [47]. Then, the DR4 site in the $A B C A 1$ promoter is able to be activated by LXR, which is critical to the upregulation of ABCA1 and cholesterol efflux [29]. LXR-mediated $A B C A 1$ gene expression plays an important role in hepatic HDL biogenesis and macrophage cholesterol efflux [48]. Particularly in pancreatic beta cells, our results indicated that OxLDL decreased $A B C A 1$ transcription by reducing the nuclear content of LXR in INS-1 cells and this reduction was prevented by addition of HDL. As shown in previous reports, transcription factor peroxisome proliferator activator receptors (PPARs) was also downstream of ERK pathway [49] and activated pancreatic ABCA1 expression [50]. Recently, RXR has been proposed as one of the therapeutic targets for treating obesity-related metabolic disorder. A novel small molecule agonist of RXR, UAB126 could prevent high-fat diet induced glucose intolerance [51] and retinoic acid isomer; 9ciRA balanced cholesterol homeostasis by regulating ABCA1 expression [52]. Further experiments will be needed to clarify a network regulation of several transcriptional factors including LXR, RXR, and PPARs in OxLDL-suppressed pancreatic ABCA1.

In summary, OxLDL suppresses the expression of pancreatic ABCA1 via MEK/ERK/LXR pathway, leading to cholesterol accumulation and the inability of INS-1 cells to secrete insulin. These findings provide a basic molecular knowledge in the effect of lipotoxicity on beta cell function, contributing to the understanding the pathological mechanism of T2D.

Author Contributions: J.L.: Investigation; Conceptualization; Methodology; Resources; Project administration; Formal analysis; Software; Writing-Original Draft; Funding acquisition. K.F.: Investigation; Conceptualization; Resources; Methodology; Formal analysis; Validation; Writing-Original Draft. H.I. (Hitomi Imachi): Conceptualization; Project administration; Methodology; Validation; Writing-Review \& Editing. S.S.: Investigation; Project administration; Funding acquisition; WritingReview \& Editing. T.K., T.S., T.I., T.Y.: Investigation; Project administration; Methodology; WritingReview \& Editing. H.I. (Hisakazu Iwama): Software; Gene analysis; Resources; Writing-Review \& Editing. K.M.: Writing—Review \& Editing; Supervision, Project administration; Funding acquisition. All authors have read and agreed to the published version of the manuscript.

Funding: This work was funded in part by Grant-in-Aid for the Ministry of Education, Culture, Sports, Science and Technology, Japan (18K08518) to K.M., Grant-in-Aid for Research activity start-up (19K23970) to S.S., and Grant-in-Aid for Early-Career Scientists (20K17513) to J.L.

Institutional Review Board Statement: Not applicable.

Informed Consent Statement: Not applicable.

Data Availability Statement: The datasets used and/or analysed during the current study are available from the corresponding author upon reasonable request.

Acknowledgments: We thank Azusa Sugimoto and Miyo Ozaki for their technical assistance. 
Conflicts of Interest: The authors declare that they have no conflict of interest.

\begin{abstract}
Abbreviations
OxLDL, oxidized low-density lipoprotein; HDL, high-density lipoprotein; ER, endoplasmic reticulum; LXR, liver X receptor; RXR, retinoid X receptor; LOX-1, lectin-type oxidized LDL receptor 1; ChIP, chromatin immunoprecipitation; GSIS, glucose-stimulated insulin secretion; PI3K, phosphatidylinositol 3 kinase; MEK, mitogen-activated protein kinase kinase; JNK, c-Jun N-terminal kinase; p38 MAPK, p38 mitogen-activated protein kinases; ERK, extracellular signal-regulated kinase; IGF-1, insulin-like growth factor-1; TD, Tangier disease; CVDs, cardiovascular diseases.
\end{abstract}

\title{
References
}

1. Morimoto, A.; Nishimura, R.; Tajima, N. Trends in the Epidemiology of Patients with Diabetes in Japan. Jpn. Med. Assoc. J. 2010, $53,36-40$.

2. Singh, R.; Devi, S.; Gollen, R. Role of free radical in atherosclerosis, diabetes and dyslipidaemia: Larger-than-life. Diabetes Metab. Res. Rev. 2015, 31, 113-126. [CrossRef] [PubMed]

3. Njajou, O.T.; Kanaya, A.M.; Holvoet, P.; Connelly, S.; Strotmeyer, E.S.; Harris, T.B.; Cummings, S.R.; Hsueh, W.C.; Health, A.B.C.S. Association between oxidized LDL, obesity and type 2 diabetes in a population-based cohort, the Health, Aging and Body Composition Study. Diabetes Metab. Res. Rev. 2009, 25, 733-739. [CrossRef] [PubMed]

4. Okajima, F.; Kurihara, M.; Ono, C.; Nakajima, Y.; Tanimura, K.; Sugihara, H.; Tatsuguchi, A.; Nakagawa, K.; Miyazawa, T.; Oikawa, S. Oxidized but not acetylated low-density lipoprotein reduces preproinsulin mRNA expression and secretion of insulin from HIT-T15 cells. Biochim. Biophys. Acta 2005, 1687, 173-180. [CrossRef] [PubMed]

5. Scazzocchio, B.; Vari, R.; D'Archivio, M.; Santangelo, C.; Filesi, C.; Giovannini, C.; Masella, R. Oxidized LDL impair adipocyte response to insulin by activating serine/threonine kinases. J. Lipid Res. 2009, 50, 832-845. [CrossRef]

6. Song, G.; Wu, X.; Zhang, P.; Yu, Y.; Yang, M.; Jiao, P.; Wang, N.; Song, H.; Wu, Y.; Zhang, X.; et al. High-density lipoprotein inhibits Ox-Ldl-Induced adipokine secretion by upregulating SR-BI expression and suppressing ER Stress pathway. Sci. Rep. 2016, 6, 30889. [CrossRef]

7. Li, S.; Kievit, P.; Robertson, A.K.; Kolumam, G.; Li, X.; von Wachenfeldt, K.; Valfridsson, C.; Bullens, S.; Messaoudi, I.; Bader, L.; et al. Targeting oxidized LDL improves insulin sensitivity and immune cell function in obese Rhesus macaques. Mol. Metab. 2013, 2, 256-269. [CrossRef]

8. Yoshida, H.; Kondratenko, N.; Green, S.; Steinberg, D.; Quehenberger, O. Identification of the lectin-like receptor for oxidized low-density lipoprotein in human macrophages and its potential role as a scavenger receptor. Biochem. J. 1998,334 Pt 1, 9-13. [CrossRef]

9. Chen, M.; Masaki, T.; Sawamura, T. LOX-1, the receptor for oxidized low-density lipoprotein identified from endothelial cells: Implications in endothelial dysfunction and atherosclerosis. Pharmacol. Ther. 2002, 95, 89-100. [CrossRef]

10. Yu, M.; Jiang, M.; Chen, Y.; Zhang, S.; Zhang, W.; Yang, X.; Li, X.; Li, Y.; Duan, S.; Han, J.; et al. Inhibition of Macrophage CD36 Expression and Cellular Oxidized Low Density Lipoprotein (Oxldl) Accumulation by Tamoxifen: A Peroxisome ProliferatorActivated Receptor (PPAR)gamma-Dependent Mechanism. J. Biol. Chem. 2016, 291, 16977-16989. [CrossRef] [PubMed]

11. Koga, M.; Kanaoka, Y.; Okamoto, M.; Nakao, Y.; Inada, K.; Takayama, S.; Kataoka, Y.; Yamauchi, A. Varenicline aggravates atherosclerotic plaque formation in nicotine-pretreated ApoE knockout mice due to enhanced oxLDL uptake by macrophages through downregulation of ABCA1 and ABCG1 expression. J. Pharmacol. Sci. 2020, 142, 9-15. [CrossRef] [PubMed]

12. Jeurissen, M.L.J.; Walenbergh, S.M.A.; Houben, T.; Gijbels, M.J.J.; Li, J.; Hendrikx, T.; Oligschlaeger, Y.; van Gorp, P.J.; Binder, C.J.; Donners, M.; et al. Prevention of oxLDL uptake leads to decreased atherosclerosis in hematopoietic NPC1-Deficient Ldlr(-/-) mice. Atherosclerosis 2016, 255, 59-65. [CrossRef] [PubMed]

13. Zhou, Y.P.; Grill, V. Long term exposure to fatty acids and ketones inhibits B-cell functions in human pancreatic islets of Langerhans. J. Clin. Endocrinol. Metab. 1995, 80, 1584-1590. [CrossRef] [PubMed]

14. Fielding, C.J.; Fielding, P.E. Molecular physiology of reverse cholesterol transport. J. Lipid Res. 1995, 36, 211-228. [CrossRef]

15. Brunham, L.R.; Kruit, J.K.; Pape, T.D.; Timmins, J.M.; Reuwer, A.Q.; Vasanji, Z.; Marsh, B.J.; Rodrigues, B.; Johnson, J.D.; Parks, J.S.; et al. Beta-cell ABCA1 influences insulin secretion, glucose homeostasis and response to thiazolidinedione treatment. Nat. Med. 2007, 13, 340-347. [CrossRef]

16. Brunham, L.R.; Kruit, J.K.; Verchere, C.B.; Hayden, M.R. Cholesterol in islet dysfunction and type 2 diabetes. J. Clin. Investig. 2008, 118, 403-408. [CrossRef] [PubMed]

17. Lyu, J.; Imachi, H.; Fukunaga, K.; Sato, S.; Ibata, T.; Kobayashi, T.; Dong, T.; Yoshimoto, T.; Yonezaki, K.; Nagata, H.; et al. Angiotensin II induces cholesterol accumulation and impairs insulin secretion by regulating Abca1 in beta cells. J. Lipid Res. 2018, 59, 1906-1915. [CrossRef] [PubMed]

18. Zhu, Y.; Liao, H.; Xie, X.; Yuan, Y.; Lee, T.S.; Wang, N.; Wang, X.; Shyy, J.Y.; Stemerman, M.B. Oxidized LDL downregulates ATP-binding cassette transporter-1 in human vascular endothelial cells via inhibiting liver $\mathrm{X}$ receptor (LXR). Cardiovasc. Res. 2005, 68, 425-432. [CrossRef] [PubMed] 
19. Lin, H.C.; Lii, C.K.; Chen, H.C.; Lin, A.H.; Yang, Y.C.; Chen, H.W. Andrographolide Inhibits Oxidized LDL-Induced Cholesterol Accumulation and Foam Cell Formation in Macrophages. Am. J. Chin. Med. 2018, 46, 87-106. [CrossRef]

20. Ho, C.M.; Ho, S.L.; Jeng, Y.M.; Lai, Y.S.; Chen, Y.H.; Lu, S.C.; Chen, H.L.; Chang, P.Y.; Hu, R.H.; Lee, P.H. Accumulation of free cholesterol and oxidized low-density lipoprotein is associated with portal inflammation and fibrosis in nonalcoholic fatty liver disease. J. Inflamm. 2019, 16, 7. [CrossRef]

21. Holvoet, P.; Lee, D.H.; Steffes, M.; Gross, M.; Jacobs, D.R., Jr. Association between circulating oxidized low-density lipoprotein and incidence of the metabolic syndrome. JAMA J. Am. Med Assoc. 2008, 299, 2287-2293. [CrossRef] [PubMed]

22. Lee, S.Y.; Hong, I.K.; Kim, B.R.; Shim, S.M.; Sung Lee, J.; Lee, H.Y.; Soo Choi, C.; Kim, B.K.; Park, T.S. Activation of sphingosine kinase 2 by endoplasmic reticulum stress ameliorates hepatic steatosis and insulin resistance in mice. Hepatology 2015, 62, 135-146. [CrossRef] [PubMed]

23. Lyu, J.; Imachi, H.; Fukunaga, K.; Sato, S.; Kobayashi, T.; Dong, T.; Saheki, T.; Matsumoto, M.; Iwama, H.; Zhang, H.; et al. Role of ATP-binding cassette transporter A1 in suppressing lipid accumulation by glucagon-like peptide-1 agonist in hepatocytes. Mol. Metab. 2020, 34, 16-26. [CrossRef]

24. Fukunaga, K.; Imachi, H.; Lyu, J.; Dong, T.; Sato, S.; Ibata, T.; Kobayashi, T.; Yoshimoto, T.; Yonezaki, K.; Matsunaga, T.; et al. IGF1 suppresses cholesterol accumulation in the liver of growth hormone-deficient mice via the activation of ABCA1. Am. J. Physiol. Endocrinol. Metab. 2018, 315, E1232-E1241. [CrossRef]

25. Li, J.; Murao, K.; Imachi, H.; Masugata, H.; Iwama, H.; Tada, S.; Zhang, G.X.; Kobayashi, R.; Ishida, T.; Tokumitsu, H. Exendin-4 regulates pancreatic ABCA1 transcription via Camkk/Camkiv pathway. J. Cell. Mol. Med. 2010, 14, 1083-1087. [CrossRef]

26. Fryirs, M.A.; Barter, P.J.; Appavoo, M.; Tuch, B.E.; Tabet, F.; Heather, A.K.; Rye, K.A. Effects of high-density lipoproteins on pancreatic beta-cell insulin secretion. Arterioscler. Thromb. Vasc. Biol. 2010, 30, 1642-1648. [CrossRef] [PubMed]

27. Haefliger, J.A.; Martin, D.; Favre, D.; Petremand, Y.; Mazzolai, L.; Abderrahmani, A.; Meda, P.; Waeber, G.; Allagnat, F. Reduction of connexin 36 content by ICER-1 contributes to insulin-secreting cells apoptosis induced by oxidized LDL particles. PLoS ONE 2013, 8, e55198. [CrossRef]

28. Zhang, Z.; Zhang, D.; Du, B.; Chen, Z. Hyperoside inhibits the effects induced by oxidized low-density lipoprotein in vascular smooth muscle cells via oxLDL-LOX-1-ERK pathway. Mol. Cell. Biochem. 2017, 433, 169-176. [CrossRef]

29. Costet, P.; Luo, Y.; Wang, N.; Tall, A.R. Sterol-dependent transactivation of the ABC1 promoter by the liver X receptor/retinoid X receptor. J. Biol. Chem. 2000, 275, 28240-28245. [CrossRef]

30. Gautam, S.; Banerjee, M. The macrophage Ox-LDL receptor, CD36 and its association with type II diabetes mellitus. Mol. Genet. Metab. 2011, 102, 389-398. [CrossRef] [PubMed]

31. Moon, J.S.; Karunakaran, U.; Elumalai, S.; Lee, I.K.; Lee, H.W.; Kim, Y.W.; Won, K.C. Metformin prevents glucotoxicity by alleviating oxidative and ER stress-induced CD36 expression in pancreatic beta cells. J. Diabetes Complicat. 2017, 31, 21-30. [CrossRef]

32. Drew, B.G.; Duffy, S.J.; Formosa, M.F.; Natoli, A.K.; Henstridge, D.C.; Penfold, S.A.; Thomas, W.G.; Mukhamedova, N.; de Courten, B.; Forbes, J.M.; et al. High-density lipoprotein modulates glucose metabolism in patients with type 2 diabetes mellitus. Circulation 2009, 119, 2103-2111. [CrossRef] [PubMed]

33. Lenzen, S.; Kloppel, G. Insulin secretion and the morphological and metabolic characteristics of pancreatic islets of hyperthyroid ob/ob mice. Endocrinology 1978, 103, 1546-1555. [CrossRef] [PubMed]

34. Miyai, Y.; Murao, K.; Imachi, H.; Li, J.; Nishiuchi, Y.; Masugata, H.; Iwama, H.; Kushida, Y.; Ishida, T.; Haba, R. Exendin-4 regulates the expression of the ATP-binding cassette transporter A1 via transcriptional factor PREB in the pancreatic beta cell line. J. Endocrinol. Investig. 2011, 34, e268-e274. [CrossRef]

35. Lyu, J.; Imachi, H.; Iwama, H.; Zhang, H.; Murao, K. Insulin-like Growth Factor 1 Regulates the Expression of ATP-Binding Cassette Transporter A1 in Pancreatic Beta Cells. Horm. Metab. Res. 2016, 48, 338-344. [CrossRef]

36. Sato, S.; Imachi, H.; Lyu, J.; Miyai, Y.; Fukunaga, K.; Dong, T.; Ibata, T.; Kobayashi, T.; Yoshimoto, T.; Kikuchi, F.; et al. Effect of TNF-alpha on the expression of ABCA1 in pancreatic beta-cells. J. Mol. Endocrinol. 2018, 61, 185-193. [CrossRef]

37. Mott, S.; Yu, L.; Marcil, M.; Boucher, B.; Rondeau, C.; Genest, J., Jr. Decreased cellular cholesterol efflux is a common cause of familial hypoalphalipoproteinemia: Role of the ABCA1 gene mutations. Atherosclerosis 2000, 152, 457-468. [CrossRef]

38. Koseki, M.; Matsuyama, A.; Nakatani, K.; Inagaki, M.; Nakaoka, H.; Kawase, R.; Yuasa-Kawase, M.; Tsubakio-Yamamoto, K.; Masuda, D.; Sandoval, J.C.; et al. Impaired insulin secretion in four Tangier disease patients with ABCA1 mutations. J. Atheroscler. Thromb. 2009, 16, 292-296. [CrossRef] [PubMed]

39. Ma, Z.; Ketelhuth, D.F.J.; Wirstrom, T.; Ohki, T.; Forteza, M.J.; Wang, H.; Grill, V.; Wollheim, C.B.; Bjorklund, A. Increased uptake of oxLDL does not exert lipotoxic effects in insulin-secreting cells. J. Mol. Endocrinol. 2019, 62, 159-168. [CrossRef]

40. Hong, D.; Bai, Y.P.; Gao, H.C.; Wang, X.; Li, L.F.; Zhang, G.G.; Hu, C.P. Ox-LDL induces endothelial cell apoptosis via the LOX-1-dependent endoplasmic reticulum stress pathway. Atherosclerosis 2014, 235, 310-317. [CrossRef]

41. Duff, J.L.; Marrero, M.B.; Paxton, W.G.; Schieffer, B.; Bernstein, K.E.; Berk, B.C. Angiotensin II signal transduction and the mitogen-activated protein kinase pathway. Cardiovasc. Res. 1995, 30, 511-517. [CrossRef]

42. Crews, C.M.; Alessandrini, A.; Erikson, R.L. The primary structure of MEK, a protein kinase that phosphorylates the ERK gene product. Science 1992, 258, 478-480. [CrossRef] [PubMed] 
43. Yamamoto, K.; Kakino, A.; Takeshita, H.; Hayashi, N.; Li, L.; Nakano, A.; Hanasaki-Yamamoto, H.; Fujita, Y.; Imaizumi, Y.; Toyama-Yokoyama, S.; et al. Oxidized LDL (oxLDL) activates the angiotensin II type 1 receptor by binding to the lectin-like oxLDL receptor. FASEB J. Off. Publ. Fed. Am. Soc. Exp. Biol. 2015, 29, 3342-3356. [CrossRef]

44. Chen, Y.; Duan, Y.; Yang, X.; Sun, L.; Liu, M.; Wang, Q.; Ma, X.; Zhang, W.; Li, X.; Hu, W.; et al. Inhibition of ERK1/2 and activation of LXR synergistically reduce atherosclerotic lesions in ApoE-deficient mice. Arterioscler. Thromb. Vasc. Biol. 2015, 35, 948-959. [CrossRef] [PubMed]

45. Mulay, V.; Wood, P.; Manetsch, M.; Darabi, M.; Cairns, R.; Hoque, M.; Chan, K.C.; Reverter, M.; Alvarez-Guaita, A.; Rye, K.A.; et al. Inhibition of mitogen-activated protein kinase Erk1/2 promotes protein degradation of ATP binding cassette transporters A1 and G1 in CHO and HuH7 cells. PLoS ONE 2013, 8, e62667. [CrossRef] [PubMed]

46. Zhao, C.; Dahlman-Wright, K. Liver X receptor in cholesterol metabolism. J. Endocrinol. 2010, 204, 233-240. [CrossRef]

47. Morel, E.; Demignot, S.; Chateau, D.; Chambaz, J.; Rousset, M.; Delers, F. Lipid-dependent bidirectional traffic of apolipoprotein B in polarized enterocytes. Mol. Biol. Cell 2004, 15, 132-141. [CrossRef]

48. Lake, N.J.; Taylor, R.L.; Trahair, H.; Harikrishnan, K.N.; Curran, J.E.; Almeida, M.; Kulkarni, H.; Mukhamedova, N.; Hoang, A.; Low, H.; et al. TRAK2, a novel regulator of ABCA1 expression, cholesterol efflux and HDL biogenesis. Eur. Heart J. 2017, 38, 3579-3587. [CrossRef] [PubMed]

49. Prusty, D.; Park, B.H.; Davis, K.E.; Farmer, S.R. Activation of MEK/ERK signaling promotes adipogenesis by enhancing peroxisome proliferator-activated receptor gamma (PPARgamma) and C/EBPalpha gene expression during the differentiation of 3T3-L1 preadipocytes. J. Biol. Chem. 2002, 277, 46226-46232. [CrossRef] [PubMed]

50. Dong, T.; Lyu, J.; Imachi, H.; Kobayashi, T.; Fukunaga, K.; Sato, S.; Ibata, T.; Yoshimoto, T.; Yonezaki, K.; Iwama, H.; et al. Selective peroxisome proliferator-activated receptor-alpha modulator K-877 regulates the expression of ATP-binding cassette transporter A1 in pancreatic beta cells. Eur. J. Pharmacol. 2018, 838, 78-84. [CrossRef] [PubMed]

51. Ren, G.; Kim, T.; Kim, H.S.; Young, M.E.; Muccio, D.D.; Atigadda, V.R.; Blum, S.I.; Tse, H.M.; Habegger, K.M.; Bhatnagar, S.; et al. A Small Molecule, UAB126, Reverses Diet-Induced Obesity and its Associated Metabolic Disorders. Diabetes 2020, 69, 2003-2016. [CrossRef] [PubMed]

52. Chen, J.; Costa, L.G.; Guizzetti, M. Retinoic acid isomers up-regulate ATP binding cassette A1 and G1 and cholesterol efflux in rat astrocytes: Implications for their therapeutic and teratogenic effects. J. Pharmacol. Exp. Ther. 2011, 338, 870-878. [CrossRef] [PubMed] 